\title{
THE EFFECT OF ATMOSPHERIC PRESSURE AND WATER TEMPERATURE ON THE SWIMMING ACTIVITY OF ROUND GOBY, NEOGOBIUS MELANOSTOMUS (ACTINOPTERYGII: PERCIFORMES: GOBIIDAE)
}

\author{
Veniamin ZAMOROV ${ }^{1}$, Yuriy KARAVANSKIY ${ }^{1}$, Yevhen LEONCHYK ${ }^{1}$, \\ Volodymyr GANDZYURA², and Yuriy $\mathrm{KVACH}^{3}$ \\ ${ }^{1}$ Department of Hydrobiology and General Ecology, Odessa I. I. Mechnikov National University, Odessa, Ukraine \\ ${ }^{2}$ Institute of Biology and Medicine, Kyiv National Taras Shevchenko University, Kyiv, Ukraine \\ ${ }^{3}$ Institute of Marine Biology, National Academy of Science of Ukraine, Odessa, Ukraine
}

Zamorov V.V., Karavanskiy Y., Leonchyk Y., Gandzyura V., Kvach Y. 2018. The effect of atmospheric pressure and water temperature on the swimming activity of round goby, Neogobius melanostomus (Actinopterygii: Perciformes: Gobiidae). Acta Ichthyol. Piscat. 48 (4): 373-379.

Background. Atmospheric pressure is one of the most important factors affecting fish activity, but the potential influence on migration patterns of fish lacking a gas bladder is unclear. In this study, we analysed the influence of atmospheric pressure on round goby, Neogobius melanostomus (Pallas, 1814), from the coastal waters of the Black Sea.

Material and methods. Gobies were maintained at low pressure, decreased by $1333 \mathrm{~Pa}(=10 \mathrm{mmHg})$, for several hours a day at temperature intervals of $10-12^{\circ} \mathrm{C}, 14-16^{\circ} \mathrm{C}, 18-20^{\circ} \mathrm{C}, 22-24^{\circ} \mathrm{C}$, and $26-28^{\circ} \mathrm{C}$ for 5 days and subsequently the pressure was returned to $1333 \mathrm{~Pa}$ and the results were compared to controls without pressure/ temperature changes.

Results. We found that increasing the atmospheric pressure at temperatures $10-24^{\circ} \mathrm{C}$ influenced the activity of round goby, which then stabilised within one hour. Fish activity then decreased till it matches the level observed before experimental pressure changes. Changes in atmospheric pressure did not influence fish activity at higher temperatures of $26-28^{\circ} \mathrm{C}$.

Conclusions. We intended to determine the influence of atmospheric pressure and water temperature on the swimming activity of round goby. The association between the atmospheric pressure, thermal tolerance, and the fish activity levels is suggested as a possible mechanism driving migrations of the round goby.

Keywords: fish physiology, fish behaviour, swimming activity, round goby, atmospheric pressure, barometric pressure, diel migration

\section{INTRODUCTION}

The round goby, Neogobius melanostomus (Pallas, 1814), is a Ponto-Caspian gobiid fish with a natural range in brackish waters and the lower reaches of rivers in the Black, Marmara, and Caspian Sea basins (Kottelat and Freyhof 2007). This fish species is also invasive in many waterways, lakes, and brackish-water systems in Europe and North America (Roche et al. 2013), and has even been recorded in tidal zones (Verreycken et al. 2011, Brunken et al. 2012, Hempel and Thiel 2013). In the Black Sea and the Sea of Azov, round goby is the most numerous fish species among commercially important gobiids (Manilo 2014, Demchenko et al. 2017).

Various environmental factors, both biotic and abiotic, have had a strong impact on the landings of commercial fisheries (Speers and Gillis 2012), including round goby
(Zamorov et al. 2015, Popov et al. 2016). Influence of electromagnetic waves, geomagnetic fields, tidal activity, etc., on fish migration are well known (Walker et al. 1982, Lassig 1983, Metcalfe et al. 1990, Fulton and Bellwood 2005, Henderson et al. 2014), whereas motor activity of fish is essentially dependent on other environmental factors, such as illumination and temperature (Matishov et al. 2009). The atmospheric pressure is one of the most important factors driving the activity of fish (Feyrer et al. 2015). For example, the influence of the atmospheric pressure on the spawning activity of anadromous fish, i.e., salmonids, is well known (Peterson 1972). Fish migrations before storms are also caused by changes in atmospheric pressure (Heupel et al. 2003). The daily absence of fish from reefs can also be associated with days of lower atmospheric pressure with high correlation with water temperature (Currey et al. 2015).

* Correspondence: Dr Yuriy Kvach, Institute of Marine Biology, National Academy of Science of Ukraine, Vul. Pushkinska 37, 65011 Odessa, Ukraine, phone/fax: +38(048) 725-09-18, e-mail: (YK) yuriy.kvach@gmail.com, (VZ)v.zamorov@onu.edu.ua, (YuKa)tetra2000@ukr.net, (YL) leonchik@ukr.net, (VG)gandzyura@gmail.com. 
Water temperature is often documented to modify fish swimming activity, which generally decreases at both the lower and the upper temperature extremes (Colchen et al. 2017). Declines in atmospheric pressure have been recorded to influence the movements of sharks (Heupel et al. 2003). Cvetkov (1982) also confirmed that changes in atmospheric pressure resulted in decreasing activity of freshwater fishes.

It is unclear how fishes without gas bladders react to changes in atmospheric pressure. According to Henderson et al. (2014), summer flounder, Paralichthys dentatus (Linnaeus, 1766), migrate from artificial reefs with declining atmospheric pressure. Reception of atmospheric pressure changes could be provided by receptors of body surface or different internal organs (Gonzales et al. 2008). Round goby, as a representative of the Neogobiinae group, lacks a swim bladder. This fish, however, is an efficient swimmer, exhibiting high swimming activity and positive rheotaxis (Tierney et al. 2011).

In this study, we intended to determine the influence of atmospheric pressure and water temperature on the swimming activity of round goby. Given that the number of fish captured is dependent on their swimming activity (which is dependent on meteorological and hydrological parameters, respectively), the findings of this research could have implications for understanding fisheries catch in Ukraine and management of invasive populations in Europe and North America.

\section{MATERIAL AND METHODS}

Round gobies were sampled with gillnets (18-24 mm mesh size) in the coastal zone of the Gulf of Odessa, Black Sea, Ukraine in August 2012. The gillnets were set for 12 $\mathrm{h}$ through the night at the depth of 4-5 m. Five individuals of round goby, Neogobius melanostomus (two males and three females), were selected for the experimental study. The low number of fish was used to facilitate further identification of fish individuals. The gender ratio in this study reflected the ratio commonly observed under natural conditions (Smirnov 1986). The total length of the gobies studied ranged from 13 to $15 \mathrm{~cm}$ (mean \pm standard deviation $=14.5 \pm 0.4$ ). Aerated containers filled with water from the sampling site were used to transport the live fish to the laboratory of the Department of Hydrobiology and General Ecology, University of Odessa.

The experiments were carried out from September through December 2012, using the following methods. Fish were held in aerated aquarium for 20 days to facilitate acclimation to artificial conditions and were then moved to 600-L experimental aquariums (110 cm long, $110 \mathrm{~cm}$ wide, and $50 \mathrm{~cm}$ high) filled with natural Black Sea water of the following parameters: salinity $14 \%$, ammonium $<0.005 \mathrm{mg}$ $\cdot \mathrm{L}^{-1}$, nitrites $<0.005 \mathrm{mg} \cdot \mathrm{L}^{-1}$, nitrates $<0.05 \mathrm{mg} \cdot \mathrm{L}^{-1}, \mathrm{pH}$ 8.0 , oxygen $8.4 \mathrm{mg} \cdot \mathrm{L}^{-1}$. To maintain stable hydrochemical conditions, $10 \%$ of the water volume was changed every 10 days. The water quality was tested using standard aquaria hydrochemical tests (Tetra, Germany). Water temperature was maintained at $23-24^{\circ} \mathrm{C}$ and filtered using external aquarium filters (Jebo-803, USA). Fish were fed once a day with frozen blue-mussel meat and chironomid larvae.
The experimental aquaria were densely covered by glass caps with an opening for feeding the fish and water quality control. To change the atmospheric pressure, aquaria walls were connected (through the fitting opening) to a compressor to provide additional air pressure (Fig. 1). Pressure level was regulated by taps, installed on the airway and controlled by a laboratory water barometer. First, the swimming activity of gobies was controlled without pressure changes. The observations were taken from 3 September through 26 October 2012, with temperature intervals: $10-12^{\circ} \mathrm{C}, 14-16^{\circ} \mathrm{C}, 18-20^{\circ} \mathrm{C}, 22-24^{\circ} \mathrm{C}$, and $26-$ $28^{\circ} \mathrm{C}$. The temperature was artificially changed during a diel cycle. When a cycle was finished the next one started. Air pressure during this period varied from 99858.5 to $101991.6 \mathrm{~Pa}$ (Table 1). Video registration of swimming activity was provided from 10:00 to $15: 00 \mathrm{~h}$ for 10 days.

Two series of laboratory experiments with changes of atmospheric pressure were conducted for 4 months (November 2013-February 2014). To avoid differences in individual physiological parameters of the fish, the same group of fish were used for all experiments.

First treatment (decreased atmospheric pressure). The pressure did not change during the period from 10:00 to 11:00 $\mathrm{h}$. Then, during the next two minutes, the pressure was decreased by $1333 \mathrm{~Pa}(=10 \mathrm{mmHg})$ and maintained at the same level from 11:00 to 13:00 h. At 13:00 h the pressure was increased (within $2 \mathrm{~min}$ ) until it reached the normal diel level. The filming of fish activity stopped at 15:00 h. Then, the water temperature was increased (see Table 1). During the next diel cycle the fish were allowed to acclimate to the new conditions, then the observations were prolonged. Within 5 days after finishing the second part of the experiment, the pressure was increased by $1333 \mathrm{~Pa}$.

Second treatment (increased atmospheric pressure. The experiment was conducted using the same protocol as in the first case. The pressure did not change during the period from 10:00 to 11:00 $\mathrm{h}$. Then, during the next two minutes,
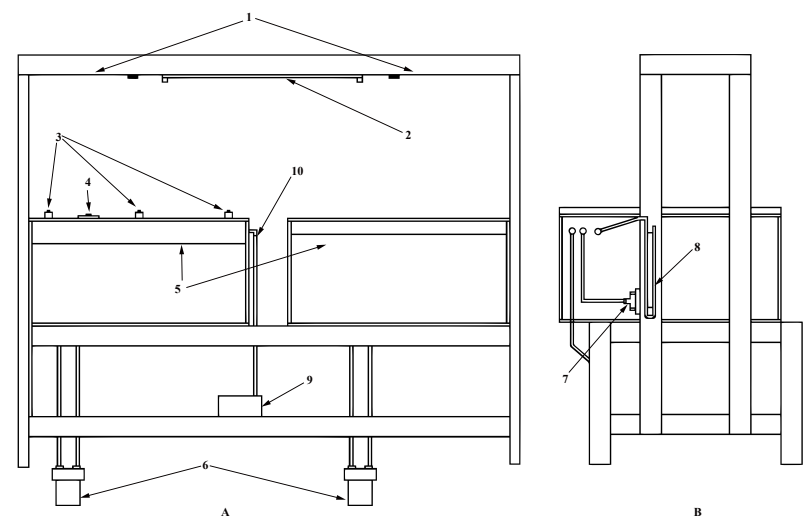

Fig. 1. Schematic diagram of the experimental aquarium; front view (A), side view (B), 1 = video cameras, 2 = light source, $3=$ glass clips, $4=$ technical opening, closed by gum cover with a clip, $5=$ water level, $6=$ external filters, $7=$ ball valve, regulating the pressure over the water, $8=$ barometer, $9=$ compressor for pressure pumping over the water, $10=$ cover glass $(20 \mathrm{~mm}$ thick $)$ 
Table 1

Atmospheric pressure and number of movements per hour of round goby, Neogobius melanostomus, studied in the autumn of 2013, within particular time intervals

\begin{tabular}{lccccc}
\hline \multirow{2}{*}{ Parameter } & \multicolumn{5}{c}{ Temperature $\left[{ }^{\circ} \mathrm{C}\right]$} \\
\cline { 2 - 6 } & $10-12$ & $14-16$ & $18-20$ & $22-24$ & $26-28$ \\
\hline $\begin{array}{l}\text { Date range } \\
\begin{array}{l}\text { Atmospheric } \\
\text { pressure }[\mathrm{Pa}]\end{array}\end{array}$ & 3 Sep-12 Sep & 14 Sep-23 Sep & 25 Sep-04 Oct & 06 Oct-15 Oct & 17 Oct-26 Oct \\
$\begin{array}{l}\text { Number } \\
\text { of movements }\end{array}$ & $1058.4-101858.3$ & $100391.8-101458.3$ & $100258.4-101725.0$ & $99858.5-101591.6$ & $100125.1-101991.6$ \\
\hline
\end{tabular}

Movement values are expressed and the mean \pm standard deviation.

the pressure was increased by $1333 \mathrm{~Pa}$ and maintained at the same level from 11:00 to 13:00 h. At 13:00 $\mathrm{h}$ the pressure was decreased (within $2 \mathrm{~min}$ ) until it reached the normal diel level. The filming of fish activity was stopped at 15:00 h.

Swimming activity was recorded using an HDDVR digital camera(Hikvision DS-2CD2432F-I, China) installed on the aquarium covering the entire experimental space. Swimming activity was filmed for one-hour intervals throughout the entire experiment. The video footage was analysed on the screen without using any software, observing and quantifying fish activity following Flink et al. (2017): $0=$ no movement, or $1=$ swimming. To evaluate swimming activity, we summarised the mean ( \pm standard deviation) movements of fish in the field of view of the digital camera during one-hour intervals.

Statistica for Windows 10 (StatSoft, 2013) was used for all data analysis. Mann-Whitney $U$-test was used to compare the time intervals of fish activities (Wilcoxon 1945). The differences were considered to be significant with $P<0.05$. All mean values are accompanied by the respective standard deviation (SD).

\section{RESULTS}

Control. In two water temperature ranges $\left(10-12^{\circ} \mathrm{C}\right.$ and $14-16^{\circ} \mathrm{C}$ ) the swimming activity of round goby did not differ significantly: 120.6 and 121.7 movements per hour, respectively (Tables 1 and 2 ). In both cases, the activity

\section{Table 2}

Matrix of Mann-Whitney $U$-test parameters for comparing the activity (mean number of movements per hour of round goby, Neogobius melanostomus, during five hours of control observations (10:00-15:00 h)

\begin{tabular}{ccccc}
\hline $\begin{array}{c}\text { Water } \\
\text { temperature }\left[{ }^{\circ} \mathrm{C}\right]\end{array}$ & $14-16$ & $18-20$ & $22-24$ & $26-28$ \\
\hline \multirow{2}{*}{$10-12$} & 0.36 & $\mathbf{2 . 0 7}$ & $\mathbf{2 . 8 0}$ & $\mathbf{2 . 8 0}$ \\
& $(0.721)$ & $(0.038)$ & $(0.005)$ & $(0.005)$ \\
$14-16$ & & $\mathbf{2 . 1 3}$ & $\mathbf{2 . 8 0}$ & $\mathbf{2 . 8 0}$ \\
& & $(0.033)$ & $(0.005)$ & $(0.005)$ \\
$18-20$ & & & $\mathbf{2 . 8 0}$ & $\mathbf{2 . 8 0}$ \\
& & & $(0.005)$ & $(0.005)$ \\
$22-24$ & & & & $\mathbf{2 . 8 0}$ \\
& & & & $(0.005)$ \\
\hline
\end{tabular}

Values in parentheses are P-values; significant differences $(P<0.05)$ are in bold. was higher than at temperatures exceeding $18^{\circ} \mathrm{C}$ (Table 2). Starting from $18-20^{\circ} \mathrm{C}$, the activity decreased for each subsequent temperature interval to reach a minimum of 70.2 movements per hour at $26-28^{\circ} \mathrm{C}$ (Table 1 ).

First treatment (decreased atmospheric pressure). Within one hour before decreasing atmospheric pressure, the number of fish movements did not differ significantly from control (see Tables 2 and 3, Fig. 2). When the pressure decreased and the temperature was maintained at $10-12^{\circ} \mathrm{C}$, the fish activity did not change (Table 3 ). After stabilization of atmospheric pressure to normal parameters, the activity significantly increased. Within one hour, the activity decreased to the parameters recorded before the experiment. The same trend was observed at $14-16^{\circ} \mathrm{C}, 18-20^{\circ} \mathrm{C}$, and $22-24^{\circ} \mathrm{C}$ (Table 3 ). No change in the activity was observed at $26-28^{\circ} \mathrm{C}$ with pressure changes (Table 3).

Second treatment (increased atmospheric pressure. As in the previous treatment, the number of fish movements in one hour before increasing atmospheric pressure did not differ significantly from control (Tables 2, 4, Fig. 3). Increasing atmospheric pressure by 1333

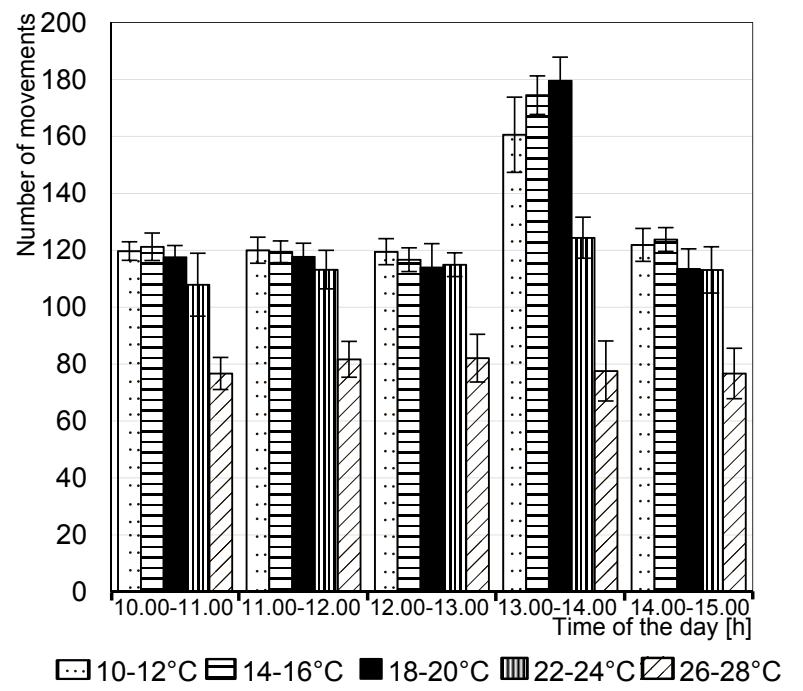

Fig. 2. Movements of round goby, Neogobius melanostomus (mean \pm standard deviation) during one hour with normal atmospheric pressure (10:00-11:00 h, 13:0015:00 h) and with atmospheric pressure decreased by $1333 \mathrm{~Pa}(11: 00-13: 00 \mathrm{~h})$ 
$\mathrm{Pa}$ (with temperature from 10 to $24^{\circ} \mathrm{C}$ ) caused an increase in fish activity (Table 4). The number of movements increased within the first hour of the experiment (11:0012:00 h). Even during the second hour after the pressure was increased, the mean activity was higher by 12.8 percentage points than normal (Tables 1, Fig. 3). After normalization (returning to the ambient pressure) of atmospheric pressure (at 13:00-15:00 h), the fish activity did not reach the parameters observed from 11:00 to 12:00 $\mathrm{h}$ (Table 4). At $26-28^{\circ} \mathrm{C}$ the association between higher fish activity and increased pressure was not observed (Table 4).

We confirmed that the increased atmospheric pressure (at $10-24^{\circ} \mathrm{C}$ ) influenced the activity of round goby but after the first hour this activity stabilised. The fish activity decreased subsequently to the level observed before experimental pressure changes. We also demonstrated that changes in atmospheric pressure did not influence the fish activity at higher temperatures $\left(26-28^{\circ} \mathrm{C}\right)$.

\section{DISCUSSION}

We determined that the activity of round goby depended on both the atmospheric pressure and the temperature. The increased atmospheric pressure at temperatures of $10-24^{\circ} \mathrm{C}$ influenced the fish activity, which subsequently stabilised within one hour. The fish activity then decreased until it reached the level observed before the experimental pressure change. Changes in the atmospheric pressure, however, did not affect the fish activity at higher temperatures $\left(26-28^{\circ} \mathrm{C}\right)$. The oxygen content decreased at higher temperatures, which had a negative effect on the fish.

The oxygen uptake rate increases with increasing temperatures (Graham 1949). The decreased oxygen consumption decreases the resting heart rate because of a low oxygen amount transported per heartbeat (Claireaux et al. 1995). According to Moskal'kova (1996), round

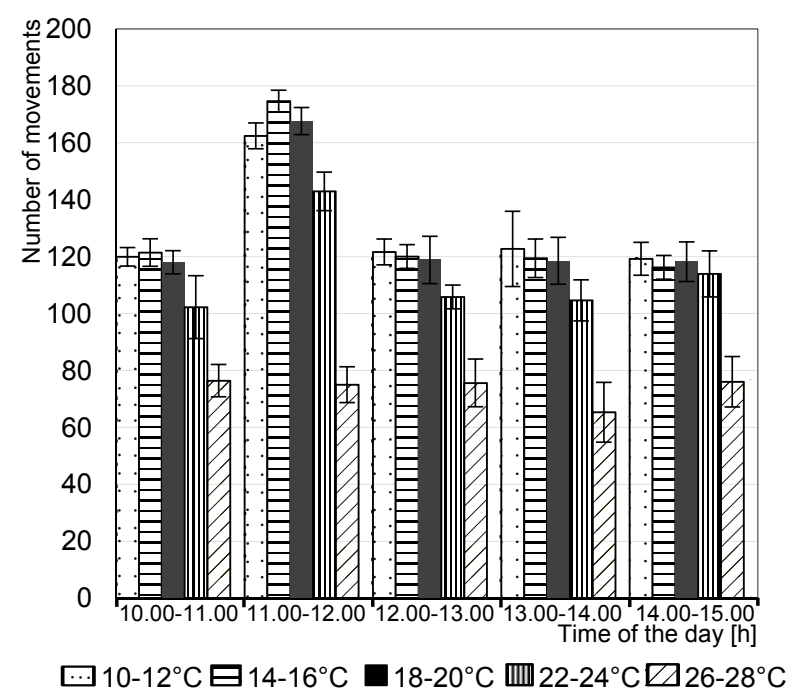

Fig. 3. Movements of round goby, Neogobius melanostomus (mean \pm standard deviation) during one hour with normal atmospheric pressure (10:00-11:00 h, 13:00 15:00 h) and with the atmospheric pressure increased by $1333 \mathrm{~Pa}(11: 00-13: 00 \mathrm{~h})$

Table 3

Matrices of Mann-Whitney $U$-test parameters for comparing the activity (mean number of movements per hour) of round goby, Neogobius melanostomus, during one hour with normal atmospheric pressure (10:00-11:00 h, 13:00-

15:00 h) and with the atmospheric pressure decreased by $1333 \mathrm{~Pa}(11: 00-13: 00 \mathrm{~h})$

\begin{tabular}{|c|c|c|c|c|c|}
\hline$t\left[{ }^{\circ} \mathrm{C}\right]$ & & $11: 00-12: 00$ & $12: 00-13: 00$ & $13: 00-14: 00$ & $14: 00-15: 00$ \\
\hline \multirow{4}{*}{ 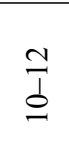 } & $10: 00-11: 00$ & $0.30(0.759)$ & $0.21(0.835)$ & $\mathbf{2 . 8 0}(0.005)$ & $0.71(0.476)$ \\
\hline & $11: 00-12: 00$ & & $0.51(0.610)$ & $2.80(0.005)$ & $0.87(0.386)$ \\
\hline & $12: 00-13: 00$ & & & $2.80(0.005)$ & $1.18(0.236)$ \\
\hline & $13: 00-14: 00$ & & & & $\mathbf{2 . 8 0}(0.005)$ \\
\hline \multirow{4}{*}{$\begin{array}{l}\underset{1}{J} \\
\pm\end{array}$} & $10: 00-11: 00$ & $0.68(0.499)$ & $2.29(0.022)$ & $2.80(0.005)$ & $1.75(0.080)$ \\
\hline & $11: 00-12: 00$ & & $1.48(0.139)$ & $2.80(0.005)$ & $1.89(0.059)$ \\
\hline & $12: 00-13: 00$ & & & $2.80(0.005)$ & $2.67(0.008)$ \\
\hline & $13: 00-14: 00$ & & & & $\mathbf{2 . 8 0}(0.005)$ \\
\hline \multirow{4}{*}{$\begin{array}{l}\stackrel{+}{1} \\
\infty\end{array}$} & $10: 00-11: 00$ & $0.36(0.721)$ & $1.58(0.114)$ & $\mathbf{2 . 8 0}(0.005)$ & $1.66(0.097)$ \\
\hline & $11: 00-12: 00$ & & $1.36(0.173)$ & $2.80(0.005)$ & $1.48(0.139)$ \\
\hline & $12: 00-13: 00$ & & & $2.80(0.005)$ & $0.41(0.683)$ \\
\hline & $13: 00-14: 00$ & & & & $\mathbf{2 . 8 0}(0.005)$ \\
\hline \multirow{4}{*}{$\begin{array}{l}\stackrel{⿱}{\sim} \\
\underset{\sim}{N}\end{array}$} & $10: 00-11: 00$ & $1.89(0.059)$ & $1.94(0.053)$ & $2.29(0.022)$ & $2.14(0.032)$ \\
\hline & $11: 00-12: 00$ & & $0.61(0.541)$ & $2.09(0.037)$ & $0.10(0.919)$ \\
\hline & $12: 00-13: 00$ & & & $2.31(0.021)$ & $0.76(0.445)$ \\
\hline & $13: 00-14: 00$ & & & & $2.24(0.025)$ \\
\hline \multirow{4}{*}{ 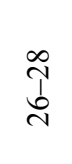 } & $10: 00-11: 00$ & $1.94(0.053)$ & $1.84(0.066)$ & $0.56(0.575)$ & $1.17(0.241)$ \\
\hline & $11: 00-12: 00$ & & $0.15(0.878)$ & $1.42(0.155)$ & $1.73(0.083)$ \\
\hline & $12: 00-13: 00$ & & & $1.17(0.241)$ & $1.68(0.093)$ \\
\hline & $13: 00-14: 00$ & & & & $0.05(0.959)$ \\
\hline
\end{tabular}

$t=$ water temperature; values in parentheses are $P$-values; significant differences $(P<0.05)$ are in bold. 
goby cannot survive at temperatures higher than $30^{\circ} \mathrm{C}$ and $26-28^{\circ} \mathrm{C}$ is the critical temperature for this fish species. According to Lee and Johnson (2005), round goby reduces oxygen consumption at $27^{\circ} \mathrm{C}$. This concurs with our observations, as we found the fish activity to decrease from a maximum at $16^{\circ} \mathrm{C}$ to a minimum at $26-28^{\circ} \mathrm{C}$, and overall lower activity at lower pressure (see Tables 1 and 3 ).

As an inhabitant of coastal shallow water, the round goby is very sensitive to changes in atmospheric pressure even by $1333 \mathrm{~Pa}$. This feature of round goby is associated with its activity during diel cycles and the increasing air pressure during migration to the coast for feeding and spawning. Gobies are active in the morning, just after dawn, which results in high catch rates of gobies by anglers (Dr Mariya Tkachenko, personal communication). Then from 12:00 till 14:00 h, gobies are usually not captured by anglers. Round goby activity is maintained only during one hour, and they are likely absent from fishing catch because all the gobies migrated from the near shore to the depth. The changes are also visible in the diel cycles of fish assemblages, with round goby becoming more numerous after dawn (2014 data; Kvač 2015).

Water temperature in the coastal zone of the Gulf of Odessa sometimes decreases to $10^{\circ} \mathrm{C}$, even in summer periods (Popov et al. 2016). These drops in the temperature are mainly caused by offshore winds, which results in the drift of warm surface waters away from the coast. These temperature changes coincide with changes in landed fisheries catch with lower abundance of gobiids in temperatures < $13^{\circ} \mathrm{C}$. The success of using gillnets and fyke nets, commonly used for commercial fisheries of gobies in the Black Sea, is dependent on the swimming activity of fish. We observed a lower activity of round goby at temperatures lower than $14^{\circ} \mathrm{C}$, which is possibly the mechanism responsible for the lower catch of gobies at this temperature.

It is important to note that the atmospheric pressure influences water level, e.g., tides (Toll and Rasmussen 2007). According to Heupel et al. (2003), tides are one of the most important environmental factors (along with atmospheric pressure) that trigger the migration of juvenile sharks, i.e., fishes lacking a swim bladder. Many species of fish have a gas bladder that allows the fish to maintain hydrostatic equilibrium (Cvetkov 1982). In fishes lacking a swim bladder, such as Ponto-Caspian gobiids, the brain is likely the only organ sensitive to atmospheric pressure, as was described for the plaice (Behan et al. 1992). Heupel et al. (2003) found that shark migrations occur when atmospheric pressure declines. In our case, the decreased atmospheric pressure did not inflict any changes in the swimming activity of gobies. Similar pressure dependencies of steady-state anisotropy indicates a straightforward translational difference between membranes of different ecological groups of fishes (Behan et al. 1992), and likely has a different influence on pelagic fishes lacking a swim bladder.

Sensitivity to changes in atmospheric pressure could explain why round goby avoids water drifts and tides. However, increasing activity could also increase predatory pressure. Because swimming activity is only maintained for one hour, it plays an important role in stimulating round goby migration. In the case of an attack from an avian predator, it should take round goby a maximum

Table 4

Matrices of Mann-Whitney $U$-test parameters for comparing the activity (mean number of movements per hour) of round goby, Neogobius melanostomus, during one hour with normal atmospheric pressure (10:00-11:00 h, 13:00-

15:00 h) and with the atmospheric pressure increased by $1333 \mathrm{~Pa}(11: 00-13: 00 \mathrm{~h})$

\begin{tabular}{|c|c|c|c|c|c|}
\hline$t\left[{ }^{\circ} \mathrm{C}\right]$ & & $11: 00-12: 00$ & $12: 00-13: 00$ & $13: 00-14: 00$ & $14: 00-15: 00$ \\
\hline \multirow{4}{*}{$\stackrel{ }{\stackrel{1}{0}}$} & 10:00-11:00 & $2.80(0.005)$ & $1.22(0.221)$ & $1.02(0.308)$ & $0.36(0.722)$ \\
\hline & $11: 00-12: 00$ & & $\mathbf{2 . 8 0}(0.005)$ & $2.80(0.005)$ & $\mathbf{2 . 8 0}(0.005)$ \\
\hline & $12: 00-13: 00$ & & & $0.46(0.445)$ & $1.13(0.260)$ \\
\hline & $13: 00-14: 00$ & & & & $1.27(0.203)$ \\
\hline \multirow{4}{*}{$\begin{array}{l}\stackrel{0}{I} \\
\pm\end{array}$} & $10: 00-11: 00$ & $\mathbf{2 . 8 0}(0.005)$ & $0.89(0.374)$ & $1.07(0.286)$ & $\mathbf{2 . 8 0}(0.005)$ \\
\hline & $11: 00-12: 00$ & & $\mathbf{2 . 8 0}(0.005)$ & $\mathbf{2 . 8 0}(0.005)$ & $\mathbf{2 . 8 0}(0.005)$ \\
\hline & $12: 00-13: 00$ & & & $0.36(0.721)$ & $1.95(0.051)$ \\
\hline & $13: 00-14: 00$ & & & & $1.78(0.074)$ \\
\hline \multirow{4}{*}{$\begin{array}{l}\stackrel{\oplus}{1} \\
\infty\end{array}$} & $10: 00-11: 00$ & $2.80(0.005)$ & $0.56(0.575)$ & $0.20(0.838)$ & $0.30(0.767)$ \\
\hline & $11: 00-12: 00$ & & $2.80(0.005)$ & $\mathbf{2 . 8 0}(0.005)$ & $\mathbf{2 . 8 0}(0.005)$ \\
\hline & $12: 00-13: 00$ & & & $0.12(0.906)$ & $0.10(0.919)$ \\
\hline & $13: 00-14: 00$ & & & & $0.83(0.407)$ \\
\hline \multirow{4}{*}{$\begin{array}{l}\stackrel{⿱}{\sim} \\
\stackrel{\sim}{\sim}\end{array}$} & $10: 00-11: 00$ & $\mathbf{2 . 8 0}(0.005)$ & $0.97(0.333)$ & $0.36(0.721)$ & $2.24(0.025)$ \\
\hline & $11: 00-12: 00$ & & $\mathbf{2 . 8 0}(0.005)$ & $\mathbf{2 . 8 0}(0.005)$ & $\mathbf{2 . 8 0}(0.005)$ \\
\hline & $12: 00-13: 00$ & & & $0.20(0.838)$ & $1.17(0.241)$ \\
\hline & $13: 00-14: 00$ & & & & $1.27(0.203)$ \\
\hline \multirow{4}{*}{$\begin{array}{l}\infty \\
\stackrel{\infty}{N} \\
\stackrel{\sim}{N}\end{array}$} & $10: 00-11: 00$ & $0.77(0.441)$ & $0.46(0.646)$ & $\mathbf{2 . 0 9}(0.037)$ & $0.51(0.610)$ \\
\hline & $11: 00-12: 00$ & & $0.31(0.760)$ & $1.90(0.058)$ & $0.24(0.813)$ \\
\hline & $12: 00-13: 00$ & & & $2.24(0.025)$ & $0.05(0.960)$ \\
\hline & $13: 00-14: 00$ & & & & $2.40(0.017)$ \\
\hline
\end{tabular}

$t=$ water temperature; values in parentheses are $P$-values; significant differences $(P<0.05)$ are in bold. 
$102 \mathrm{~s}$ to find shelter, which does not depend on the round gobies general activity (Flink et al. 2017).

Round goby is a fish species that is characterised by plasticity in life-history traits, which is associated with their success as an invasive species (Gutowsky and Fox 2012). In last decade round goby was observed in the tidal zones of river deltas of the North Sea (Verreycken et al. 2011, Brunken et al. 2012, Hempel and Thiel 2013). Because tides are absent in the Black Sea (see Popov et al. 2016), tidal habitats are not typical for Ponto-Caspian gobiids. The atmospheric pressure sensitivity of round goby explains the ability of this fish to survive in tidal zones. This adaptation to weather changes helps round goby to maintain higher activity and ultimately drives diel migrations.

We associate the increased swimming activity of round goby, caused by an increased atmospheric pressure, with influence on the hydrocarbon order of brain myelin membranes, which was observed in other benthic fish. For example, at high pressure (up to $10^{8} \mathrm{~Pa}$ ), hydrocarbons of brain myelin membranes are more disordered than in shallow water for deep-water plaice, Pleuronectes platessa Linnaeus, 1758 (see Behan et al. 1992). However, at the normal atmospheric pressure, the effect on brain myelin membranes is similar in both deep- and shallowwater fish species (Behan et al. 1992). Experiments on coastal fishes confirmed that the consumption of oxygen at high hydrostatic pressure increases in the first hour then decreases (Sebert 2002, and references therein). It is plausible that higher oxygen consumption is the result of increased swimming activity and we found that round goby activity decreased after one hour of high pressure. It is, therefore, plausible that the influence of pressure on brain myelin membrane provokes fish activity, which results in high oxygen consumption.

\section{ACKNOWLEDGEMENTS}

We thank Dr Harri Pettitt-Wade (Biological Sciences, University of Windsor, Canada) for his help with proofreading the English text.

\section{REFERENCES}

Behan M.K., Macdonald A.G., Jones G.R., Cossins A.R. 1992. Homeoviscous adaptation under pressure: The pressure dependence of membrane order in brain myelin membranes of deep-sea fish. Biochimica et Biophysica Acta 1103 (2): 317-323. DOI: 10.1016/0005-2736(92)90102-R

Brunken H., Castro J.F., Hein M., Verwold A., Winkler M. 2012. Erstnachweis der Schwarzmund-Grundel Neogobius melanostomus (Pallas, 1814) in der Weser. Lauterbornia 75: 31-37.

Claireaux G., Webber D., Kerr S., Boutilier R. 1995. Physiology and behaviour of free-swimming Atlantic cod (Gadus morhua) facing fluctuating temperature conditions. Journal of Experimental Biology 198 (1): 49-60.

Colchen T., Teletchea F., Fontaine P., Pasquet A. 2017. Temperature modifies activity, inter-individual relationships and group structure in a fish. Current Zoology 63 (2): 175-183. DOI: 10.1093/cz/zow048

Currey L.M., Heupel M.R., Simpfendorfer C.A., Williams A.J. 2015. Assessing environmental correlates of fish movement on a coral reef. Coral Reefs 34 (4): 1267-1277. DOI: 10.1007/s00338-0151318-7

Cvetkov V.I. [Tsvetkov V.I.] 1982. Vliânie izmenenij atmosfernogo davleniâ na zimnûû piŝedobyvatel'nuû aktivnost leŝa, plotvy i okunâ Ivan'kovskogo vodohraniliŝa. [The effect of changes in atmospheric pressure on winter food-producing activity of bream, roach, and perch of the Ivankovski Reservoir.] Voprosy ihtiologii 22 (3): 515-518. [In Russian.]

Demchenko V.O., Tkachenko M.Y. 2017. Biological characteristics of the round goby, Neogobius melanostomus (Pallas, 1814), from different water bodies. Archives of Polish Fisheries 25 (1): 51-61. DOI: 10.1515/aopf-2017-0006

Feyrer F., Cloern J.E., Brown L.R., Fish M.A., Hieb K.A., Baxter R.D. 2015. Estuarine fish communities respond to climate variability over both river and ocean basins. Global Change Biology 21 (10): 3608-3619. DOI: $10.1111 / \mathrm{gcb} .12969$

Flink H., Behrens J.W., Svensson P.A. 2017. Consequences of eye fluke infection on anti-predator behaviours in invasive round gobies in Kalmar Sound. Parasitology Research 116 (6): 1653-1663. DOI: 10.1007/s00436-017-5439-5

Fulton C.J., Bellwood D.R. 2005. Wave-induced water motion and the functional implications for coral reef fish assemblages. Limnology and Oceanography 50 (1): 255-264. DOI: 10.4319/1o.2005.50.1.0255

Graham J.M. 1949. Some effects of temperature and oxygen pressure on the metabolism and activity of the speckled trout, Salvelinus fontinalis. Canadian Journal of Research 27 (5): 270-288. DOI: 10.1139/ cjr49d-024

Gonzales T.T., Katoh M., Ishimatsu A. 2008. Respiratory vasculatures of the intertidal air-breathing eel goby, Odontamblyopus lacepedii (Gobiidae: Amblyopinae). Environmental Biology of Fishes 82 (4): 341-351. DOI: $10.1007 / \mathrm{s} 10641-007-9295-5$

Gutowsky L.F.G., Fox M.G. 2012. Intra-population variability of life-history traits and growth during range expansion of the invasive round goby, Neogobius melanostomus. Fisheries Management and Ecology 19 (1): 78-88. DOI: 10.1111/j.1365-2400.2011.00831.x

Hempel M., Thiel R. 2013. First records of the round goby Neogobius melanostomus (Pallas, 1814) in the Elbe River, Germany. BioInvasions Records 2 (4): 291-295. DOI: 10.3391/bir.2013.2.4.05

Henderson M.J., Fabrizio M.C., Lucy J.A. 2014. Movement patterns of summer flounder near an artificial reef: Effects of fish size and environmental cues. Fisheries Research 153: 1-8. DOI: 10.1016/j. fishres.2014.01.001

Heupel M.R., Simpfendorfer C.A., Hueter R.E. 2003. Running before the storm: Blacktip sharks respond to 
falling barometric pressure associated with Tropical Storm Gabrielle. Journal of Fish Biology 63 (5): 13571363. DOI: 10.1046/j.1095-8649.2003.00250.x

Kottelat M., Freyhof J. 2007. Handbook of European freshwater fishes. Kottelat, Cornol, Switzerland and Freyhof, Berlin, Germany.

Kvač Û. [Kvach Yu.] 2015. Vidovij sklad ryb priberežnih milin Odeskoï zatoki i jogo zmìni zaležno vìd času doby. [The fish assemblage on the coastal shallow waters of the Gulf of Odessa and its diel changes.] Studia Biologica 9 (1): 191-200. [In Ukrainian with English and Russian summaries.] DOI: 10.30970/ sbi.0901.392

Lassig B.R. 1983. The effects of a cyclonic storm on coral reef fish assemblages. Environmental Biology of Fishes 9 (1): 52-63. DOI: 10.1007/BF00001058

Lee V.A., Johnson T.B. 2005. Development of a bioenergetics model for the round goby (Neogobius melanostomus). Journal of Great Lakes Research 31: 125-134. DOI: 10.1016/S0380-1330(05)70244-6

Manilo L.G. 2014. Ryby semejstva byčkove (Perciformes, Gobiidae) morskih i solonovatyh vod Ukrainy. [Gobiid fishes (Perciformes, Gobiidae) of marine and brackish waters of Ukraine.] Naukova Dumka, Kiev, Ukraine. [In Russian.]

Matishov G.G., Zenzerov V.S., Emelina A.V., Muraveiko V.M. 2009. Changes in the motor activity and temperature resistance of shorthorn sculpin Myoxocephalus scorpius (L) from the Barents Sea. Doklady Biological Sciences 427 (1): 349-351. DOI: 10.1134/S0012496609040139

Metcalfe J.D., Arnold G.P., Webb P.W. 1990. The energetics of migration by selective tidal stream transport: An analysis for plaice tracked in the southern North Sea. Journal of the Marine Biological Association of the United Kingdom 70 (1): 149-162. DOI: $10.1017 / \mathrm{S} 0025315400034275$

Moskal'kova K.I. 1996. Ecological and morphophysiological prerequisites to range extension in the round goby Neogobius melanostomus under conditions of anthropogenic pollution. Journal of Ichthyology 36 (8): 584-590.

Peterson D.A. 1972. Barometric pressure and its effect on spawning activities of rainbow trout. Progressive Fish-Culturist 34 (2): 110-112. DOI: 10.1577/1548-8640(1972)34[110:BPAIEO]2.0.CO;2

Popov Û.I. [Popov Yu.I.], Matygin A.S., Kolomiejčenko G.Û. [Kolomeychenko G.Yu.], Zamorov V.V., Černikova C.Û. [Chernikova S.Yu.], Petrov S.A., Ponomareva L.P., Karavanskij Û.V. [Karavanskiy Y.V.], Leončik E.Û. [Leonchik E.Yu.], Kaštakov V.D. [Kashtakov V.D.] 2016. Severo-zapadnaâ čast' Černogo morâ: struktura i klimatičeskaâ izmienčivost' okeanologičeskih polej. [North-western part of the Black Sea: structure and climatic changes of oceanological fields.] FOP Popova, Odessa, Ukraine. [In Russian.]
Roche K.F., Janač M., Jurajda P. 2013. A review of gobiid expansion along the Danube-Rhine corridorgeopolitical change as a driver for invasion. Knowledge and Management of Aquatic Ecosystems 411: e01. DOI: $10.1051 / \mathrm{kmae} / 2013066$

Smirnov A.I. 1986. Okuneobraznye (byčkovye), skorpenoobraznye, kambaloobraznye, prisoskoobraznye, udil'ŝikoobraznye. Pp. 1-320. In: Ŝerbak N.N. [Shcherbak N.N.] (ed.) Fauna Ukrainy. [Fauna of Ukraine.] Naukova Dumka, Kiev, Ukraine. [In Russian.]

Sebert P. 2002. Fish at high pressure: a hundred year history. Comparative Biochemistry and Physiology Part A: Molecular and Integrative Physiology 131 (3): 575-585. DOI: 10.1016/S1095-6433(01)00509-8

Speers J., Gillis D. 2012. Catch and effort variation in the commercial gillnet fishery of Lake Winnipeg, Canada, in relation to environmental factors. Journal of Great Lakes Research 38 (Suppl. 3): 26-34. DOI: 10.1016/j. jglr.2011.05.006

Tierney K.B., Kasurak A.V., Zielinski B.S., Higgs D.M. 2011. Swimming performance and invasion potential of the round goby. Environmental Biology of Fishes 92 (4): 491-502. DOI: 10.1007/s10641-011-9867-2

Toll N.J., Rasmussen T.C. 2007. Removal of barometric pressure effects and Earth tides from observed water levels. Groundwater 45 (1): 101-105. DOI: 10.1111/j.1745-6584.2006.00254.x

Verreycken H., Breine J.J., Snoeks J., Belpaire C. 2011. First record of the round goby, Neogobius melanostomus (Actinopterygii: Perciformes: Gobiidae) in Belgium. Acta Ichthyologica et Piscatoria 41 (2): 137-140. DOI: 10.3750/AIP2011.41.2.11

Walker M., Dizon A., Kirschvink J. 1982. Geomagnetic field detection by yellowfin tuna. Pp. 755-758. In: Oceans 82 Conference Record: Industry, Government, Education-Partners in Progress, 20-22 September 1982, Washington DC, Institute of Electrical and Electronics Engineers, New York, NY, USA.

Wilcoxon F. 1945. Individual comparisons by ranking methods. Biometrics Bulletin 1 (6): 80-83. DOI: 10.2307/3001968

Zamorov V., Černikova C.Û. [Chernikova S.Yu.], Karavanskij Û.V. [Karavanskiy Yu.V.], Leončik E. U. [Leonchik E.Yu.] 2015. Dinamika setnyh ulovov byčkovyh ryb (Gobiidae) v priberežnoj zonie Odesskogo zaliva. [Dynamics of net catches of gobies (Gobiidae) in the coastal zone of the Gulf of Odessa.] Naukovì Zapiski Ternopillskogo pedagogìčnogo unìversitetu (Bìologîâ) 3-4 (64): 238-241. [In Russian with English summary.]

Received: 14 April 2018

Accepted: 20 August 2018

Published electronically: 31 December 2018 